\title{
Four aspects of English speaking difficulties encountered by tertiary English-majored students
}

\author{
Tran Quoc Thao ${ }^{1 *}$, Dang Thi Nhu Nguyet ${ }^{1}$ \\ ${ }^{1}$ Ho Chi Minh City University of Technology (HUTECH), Vietnam \\ *Corresponding author: tq.thao@hutech.edu.vn
}

\begin{abstract}
ARTICLE INFO
ABSTRACT

DOI: $10.46223 / \mathrm{HCMCOUJS.}$

soci.en.9.2.261.2019

Received: November $3^{\text {rd }}, 2019$

Revised: December $6^{\text {th }}, 2019$

Accepted: December 13 $3^{\text {th }}, 2019$

Keywords:

affective difficulties, English-majored students, instructional difficulties, linguistic difficulties, social difficulties

Being able to speak English well is one of the outcomes for English training programs in different teaching and learning contexts. Nevertheless, there are many factors affecting the achievement of a high level of English speaking skills. One of these factors is derived from English speaking difficulties that ESL/EFL learners have to endure. This study, therefore, attempts to investigate the four aspects of speaking difficulties, namely affective, social, instructional and linguistic difficulties encountered by English-majored students at one university in Ho Chi Minh City, Vietnam. One hundred and fifty participants were involved in answering the questionnaire. The results showed that English-majored students' speaking abilities were often affected by speaking difficulties. The aspect they experienced most was affective difficulties while the least was instructional difficulties. The findings also revealed that the number of years spent learning English also affected English-majored students' speaking skills.
\end{abstract}

\section{Introduction}

Speaking is obviously one of the most challenging but important skills for ESL/EFL learners (Brown, 1994; Tran \& Tham, 2015; Ur, 1999). Therefore, the communicative competence in most English training programs is emphasized as one of the learning outcomes. However, EFL learners in many countries including Vietnam cannot communicate in English well due to various reasons, both internally and externally. Most popular reasons hindering EFL learners from speaking English well are the difficulties encountered by learners during their English speaking process.

With respect to the speaking difficulties, different researchers (Aleksandrzak, 2011; Hojat \& Afghari, 2013; Shumin, 1997; Tran \& Dang, 2014) have confirmed that ESL/EFL learners of different levels face a variety of difficulties in their speaking English. They may face both linguistic and non-linguistic problems in grammar, vocabulary, affective factors, and so on. As stated by Shumin (1997) and Tran and Nguyen (2019), speaking is a stressful skill for learners because not only do they need grammar and philological knowledge but they also need knowledge of the socially appropriate language.

English-majored students of the current research also confront a number of difficulties 
in speaking English. However, such English speaking difficulties are only observed and not yet confirmed by any research. Accordingly, this study aims at investigating the difficulties in speaking English faced by English-majored students at one university in Ho Chi Minh City, Vietnam. The research questions are formed as follows:

1. What are English speaking difficulties encountered by tertiary English-majored students in Vietnam?

2. Does the number of years spent learning English affect the English-majored students' ability to speak English? If yes, how?

\section{Literature review}

Many researchers (Aleksandrzak, 2011; A-Hosni, 2014; Juhana, 2012; Nguyen \& Tran, 2015; Ur, 1999) have addressed different aspects of English speaking difficulties, namely affective difficulties, social difficulties, instructional difficulties, and linguistic difficulties.

\section{Affective difficulties}

One of the most essential difficulties of language learning achievement is the affective side of the learner. Learners' affective difficulties include fear of making mistakes, shyness, loss of self-confidence, and anxiety. According to Juhana (2012, p. 101), psychological or affective factors often discourage students from speaking English such as being afraid of mistakes, shyness, lowering anxiety, lack of confidence and lack of enthusiasm. Nguyen and Tran (2015) list many factors related to affective issues, which result in speaking difficulties. Firstly, inhibition is the concept related to or incorporated under the conception of self-esteem. Secondly, anxiety plays a main role in the verbal communication of English-majored students. Anxiety is defined as "feeling of uneasiness, frustration, self-doubt, apprehension or worry" (Brown, 1994, p. 141). It is associated with unlike kinds of nervousness such as anxiety of looking ludicrous, the anxiety of the anticipation coming from an auditor's empty look viewing that they are unsuccessful to converse (Beebe, 1983). Shumin (1997) deduces that speaking a foreign language in a community, exceptionally in the presence of natural speakers, is often anxiety-provoking. Intense anxiety sometimes arises when students become tongue-tied for words in an unanticipated state which frequently leads to disappointment and an overall intelligence failure. She also adds that students are afraid of the fact that other people would like to know how expert they are when they speak English. They are very careful about not making mistakes in what they say, for making mistakes would be a community presentation of unawareness, which would make them "lose face" in some cultures. Obviously, the compassion of ESL/EFL learners to making errors, or anxiety of "face losing" has meant their incapability to speak English well. Finally, ESL/EFL learners have no reasons to direct themselves because they lack the enthusiasm to speak English. They have no idea about the message they want to convey when speaking English. Furthermore, students' enthusiasm is impacted by both inside and outside issues. Interior enthusiasm is students' self-motivation whereas exterior motivation comes from other parties excluding self-regulation strategies.

\section{Social difficulties}

Ethnic physical characteristics of a language also involve second or foreign language learning, especially English. Carrasquillo (1994, p. 55) states that "shared values and beliefs create the traditions and social structures that bind a community together and are expressed in their language". Therefore, to speak a language, one must know how the language is used in a 
community setting. It is well known that each language has its own guidelines of control as to when and how. Berns (1990) ascertains that a speaker may execute a given oral way with his or her exchange collaborator. Because of the inspiration of their own national averages, it is hard for nonnative speakers to select the forms suitable to certain conditions.

Reluctance to speak can also be derived from expectations about the roles that teachers and students should play during classroom instruction. Tsui (1996) realizes that Asian students may be nervous not to show verbal success in front of their peers, expected to a scheduled feature of diffidence. In Asian cultures, teachers and students play very stringent roles that are seldom infringed. Scollon and Scollon (1990) state that the norms of classroom contribution require students to receive an appreciation of what is taught and keep silent even when explicitly asked to speak by the teacher. The non-Western classrooms are described by the teacher assuming an oration style of teaching and the student listening and taking notes in quietness. Few class discussions are conducted, and learners are not supposed to interpose the teacher to ask a question because that is regarded as offensive.

\section{Instructional difficulties}

In teaching speaking to ESL/EFL learners, it is necessary for the instructor and learners to interrelate with each other to portion knowledge and to sequence practicing speaking as one of the original skills to develop proficiency in collaborating with English. Nawshin (2009) states a number of reasons about teachers' instructional methods that can lead to English speaking difficulties, for example, teacher's speaking time, use of the mother tongue in the classroom and teachers' low command in speaking English.

\section{Linguistic difficulties}

ESL/EFL learners frequently have difficulties in language development because of the gaps in their language collection. One of the most problems that learners face is associated to their linguistic knowledge which refers to their incongruous association and structural acquaintance. They lack grammatical knowledge because they do not have enough basic English consciousness or they have not learned about it.

To sum up, aspects of English speaking difficulties may be varied but the current research focuses on four big aspects, namely affective difficulties, social difficulties, instructional difficulties, and linguistic difficulties, which form the theoretical framework of this study. These aspects of English speaking difficulties are chosen for this study because they can be found in the literature review. Additionally, they are seen to cover all areas of English speaking difficulties by English-majored students in the research context.

\section{Research methodology}

\subsection{Research setting and sample}

This quantitative research was conducted at a university in Ho Chi Minh City, Vietnam. The faculty of the English language has over 1,500 students, and each class has about 35 to 40 students. The students study the four English skills throughout the four years at university. For the Bachelor training program for English-Majored students, all students are required to complete eight semesters of English skills including listening, speaking, reading and writing. The English-majored students have already learned Listening and Speaking 1, 2, 3 in the first year and listening and Speaking 4, and Public speaking in the second year. These subjects are taught by Vietnamese and foreign lecturers during 45 periods. At the end of the course, English- 
majored students have an individual verbal test with their lecturers. They would talk directly with the instructor on a certain topic.

Taking part in the present research are 150 English-majored students (26 males and 124 females). The students have already learned the public speaking course in the second year. This would be an advantage to investigate their speaking difficulties. Table 1 shows the background information of participants.

\section{Table 1}

Background information about participants

\begin{tabular}{|c|c|c|c|c|}
\hline \multirow{2}{*}{ No. } & \multirow{2}{*}{ Information } & & \multicolumn{2}{|c|}{$\mathrm{N}=150$} \\
\hline & & & $\mathbf{F}$ & $\%$ \\
\hline \multirow{2}{*}{1} & \multirow{2}{*}{ Gender } & Male & 26 & 17.3 \\
\hline & & Female & 124 & 82.7 \\
\hline \multirow{4}{*}{2} & \multirow{4}{*}{ Number of English learning years } & Under 5 & 0 & 0 \\
\hline & & $5-7$ & 57 & 38.0 \\
\hline & & $8-10$ & 51 & 34.0 \\
\hline & & Over 10 & 42 & 28.0 \\
\hline \multirow{5}{*}{3} & \multirow{5}{*}{ Self-rated overall English proficiency } & Excellent & 0 & 0 \\
\hline & & Good & 11 & 7.3 \\
\hline & & Fair & 60 & 40.0 \\
\hline & & Average & 63 & 42.0 \\
\hline & & Poor & 16 & 10.7 \\
\hline \multirow{4}{*}{4} & \multirow{4}{*}{$\begin{array}{l}\text { Number of hours per day spent on } \\
\text { practicing speaking English }\end{array}$} & Less than 1 & 78 & 52.0 \\
\hline & & $1-3$ & 64 & 42.7 \\
\hline & & More than 3-5 & 5 & 3.3 \\
\hline & & More than 5 & 3 & 2.0 \\
\hline
\end{tabular}

Note: F: frequency; \%: percentage

Source: The researcher's data analysis

Table 1 shows an unequal number in the gender of participants including $17.3 \%$ males and $82.7 \%$ females. Obviously, none of them had learnt English less than 5 years with 57 participants (38\%) learning English for more than 5 years, 51 (34.0\%) from 8 to 10 years, and $42(28.0 \%)$ for over 10 years. Regarding overall English proficiency, respondents self-rated their English proficiency as average level (42\%), fair (40\%), poor (10.7\%), good $(7.3 \%)$, and none at an excellent level. In respect of time allocated to practice speaking English, it is noticed that 78 participants $(52.0 \%)$ spent less than 1 hour per day; 64 (42.7\%) from 1 to 3 hours; 5 (3.3\%) from 3 to 5 hours; and only 3 out of 150 (2.0\%) practiced speaking English more than 5 hours a day.

\subsection{Research instrument}

A closed-ended questionnaire was designed based on the theoretical framework in the literature review and consists of two main parts: Part A and Part B. The former includes questions about the background information of respondents. The latter of 12 questions about English speaking difficulties are divided into four groups including affective difficulties (items 1-3), social difficulties (items 4-6), instructional difficulties (items 7-10) and linguistic difficulties (items 11-12). All the items in Part B are designed in a 5-point Likert-scale of $1=$ 
Never; 2= Rarely; 3= Sometimes; 4= Often; 5= Always. The Cronbach's Alpha of the questionnaire is .77, and the elements of the questionnaire are affective difficulties (.83), social difficulties (.76), instructional difficulties (.70), and linguistic difficulties (.65). This means that the questionnaire was highly reliable to be used for collecting data.

\subsection{Data collection and analysis}

Before being administered to respondents, all questions in the questionnaire were translated into Vietnamese. It was then piloted to a group of 10 students who had similar characteristics to those in the main study. This is to ensure the validity of the questionnaire in terms of layout and content. The official questionnaire was administered in person to 168 students, but only 150 respondents returned the questionnaire. It took respondents from 10 to12 minutes to finish answering the questionnaire.

As far as the data analysis is concerned, the five-point Likert-scale from strongly disagree to strongly agree was interpreted in relation to mean $(\mathrm{M})$ score as follows: Never $(\mathrm{M}=$ 1.00 - 1.80); Rarely $(\mathrm{M}=1.81$ - 2.60); Sometimes $(\mathrm{M}=2.61-3.40)$; Often $(\mathrm{M}=3.41$ - 4.20); Always $(\mathrm{M}=4.21$ - 5.00). The data attained from the questionnaire were analyzed using SPSS 19.0 in which descriptive statistics in terms of mean and standard deviation were produced to examine how regularly the students encountered the given speaking difficulties. In addition, the ANOVA was employed to find out the differences in English speaking difficulties in terms of English-majored students' number of English learning years.

\section{Results and discussion}

\subsection{Results}

\subsubsection{English-majored students' English speaking difficulties}

As seen in Table 2, the overall mean of difficulties in speaking English encountered by English-majored students was 2.91 out of 5. This can be interpreted that participants often faced difficulties when speaking English.

\section{Table 2}

English speaking difficulties

\begin{tabular}{cccc}
\hline \multirow{2}{*}{12 items } & \multicolumn{3}{c}{$\mathbf{N = 1 5 0}$} \\
\cline { 2 - 3 } & $\mathbf{M}$ & SD \\
\hline English speaking difficulties & 2.91 & .61 \\
\hline
\end{tabular}

Note: M: mean; SD: Standard deviation

Source: The researcher's data analysis

With respect to four elements of English speaking difficulties, results in Table 3 indicate that the mean score of element affective difficulties is $3.46(\mathrm{SD}=.96)$, followed by social difficulties $(\mathrm{M}=3.05 ; \mathrm{SD}=.84)$ and linguistic difficulties $(\mathrm{M}=2.80 ; \mathrm{SD}=99)$. The element with the lowest mean score is instructional difficulties $(\mathrm{M}=2.34 ; \mathrm{SD}=.81)$. This means that English - majored students often suffered affective difficulties when speaking English, and they sometimes endured social difficulties and linguistic ones. Nonetheless, they rarely experienced instructional difficulties in speaking English. 


\section{Table 3}

Elements of English speaking difficulties encountered by English-Majored students

\begin{tabular}{lcc}
\hline & \multicolumn{2}{c}{$\mathbf{N = 1 5 0}$} \\
\cline { 2 - 3 } & $\mathbf{M}$ & SD \\
\hline Affective difficulties & 3.46 & .96 \\
\hline Social difficulties & 3.05 & .84 \\
\hline Instructional difficulties & 2.34 \\
\hline Linguistic difficulties & 2.80 & .81 \\
\hline
\end{tabular}

Note: M: mean; SD: Standard deviation

Source: The researcher's data analysis

Specifically, Table 3 reveals the similarity in mean scores of three items of affective difficulties. The participants reported they were often "anxious" (item 3: M=3.49; SD=1.07) and "of low self-confidence in speaking English" (item 2: $\mathrm{M}=3.45 ; \mathrm{SD}=1.11$ ). Furthermore, they often "fear of making mistakes" (item 1: $\mathrm{M}=3.45$; $\mathrm{SD}=1.13$ ). In other words, Englishmajored students seem to undergo many negative feelings when speaking English at relatively high frequency.

\section{Table 4}

English-majored students' English speaking difficulties in terms of affective difficulties

\begin{tabular}{cccc}
\hline \multirow{2}{*}{ No. } & Items & \multicolumn{2}{c}{ N=150 } \\
\cline { 3 - 4 } & & M & SD \\
\hline 1 & I fear of making mistakes. & 3.45 & 1.13 \\
\hline 2 & I am of low self-confidence in speaking English. & 3.45 & 1.11 \\
\hline 3 & I am anxious when I am speaking English. & 3.49 & 1.07 \\
\hline
\end{tabular}

Note: $\mathrm{M}=$ mean; $\mathrm{SD}=$ standard deviation

Source: The researcher's data analysis

Regarding social difficulties, Table 5 displayed that research participants often "have difficulty in finding opportunities to practice speaking English outside the classroom" (item 4: $\mathrm{M}=3.49$; $\mathrm{SD}=1.12$ ). Meanwhile, they sometimes "cannot cooperate with [their] classmates in speaking class" (item 5: $\mathrm{M}=2.89 ; \mathrm{SD}=1.17$ ), and "the speaking English class [sometimes] is not useful enough for [them] to communicate in English with others" (item 6: $\mathrm{M}=2.77 ; \mathrm{SD}=1.09$ ). It may be understood that the opportunities for English-majored students to practice speaking English outside the classroom are less than those inside classrooms. 


\section{Table 5}

English-majored students' English speaking difficulties in terms of social difficulties

\begin{tabular}{llll}
\hline \multirow{2}{*}{ No. } & \multicolumn{1}{c}{ Items } & \multicolumn{2}{c}{$\mathbf{N = 1 5 0}$} \\
\cline { 3 - 4 } & & M & SD \\
\hline 4 & $\begin{array}{l}\text { I have difficulty in finding opportunities to practice speaking English outside } \\
\text { classroom. }\end{array}$ & 3.49 & 1.12 \\
\hline 5 & I cannot cooperate with my classmates in speaking class. & 2.89 & 1.17 \\
\hline 6 & $\begin{array}{l}\text { The speaking English class is not useful enough for me to communicate in } \\
\text { English with others. }\end{array}$ & 2.77 & 1.09 \\
\hline
\end{tabular}

Note: $\mathrm{M}=$ mean; $\mathrm{SD}=$ standard deviation

Source: The researcher's data analysis

Table 6 indicated that research participants' speaking difficulty was rarely affected by their instructors' teaching methods. Specifically, their speaking was rarely affected by their "instructors' harsh error correction" (item 8: $\mathrm{M}=2.66$; $\mathrm{SD}=1.07$ ), "instructors' overuse of L1 in speaking class" (item 7: M=2.49; SD=1.10), “instructors' low command of English speaking skills" (item 9: $\mathrm{M}=2.13 ; \mathrm{SD}=1.07$ ), and "instructors" low encouraging me to speak English" (item 10: $\mathrm{M}=2.08 ; \mathrm{SD}=1.04$ ).

\section{Table 6}

English-majored students' English speaking difficulties in terms of instructional difficulties

\begin{tabular}{clcc}
\hline \multirow{2}{*}{ No. } & \multicolumn{1}{c}{ Items } & N=150 \\
\cline { 2 - 4 } & & M & SD \\
\hline 7 & $\begin{array}{l}\text { I cannot speak English much due to my instructors' overuse of L1 in } \\
\text { speaking class. }\end{array}$ & 2.49 & 1.10 \\
\hline 8 & I cannot speak English much due to my instructors' harsh error correction. & 2.66 & 1.07 \\
\hline 9 & $\begin{array}{l}\text { I cannot speak English much due to my instructors' low command of } \\
\text { English speaking skills. }\end{array}$ & 2.13 & 1.07 \\
\hline 10 & $\begin{array}{l}\text { I cannot speak English much due to my instructors' low encouraging me to } \\
\text { speak English. }\end{array}$ & 2.08 & 1.04 \\
\hline
\end{tabular}

Note: $\mathrm{M}=$ mean; $\mathrm{SD}=$ standard deviation

Source: The researcher's data analysis

The results in Table 7 show that English-majored students sometimes did not have enough "English vocabulary" (item 11: $\mathrm{M}=2.85 ; \mathrm{SD}=1.07$ ) and "English grammar knowledge" (item 12: $\mathrm{M}=2.74 ; \mathrm{SD}=1.21$ ) to communicate in English with others. In other words, linguistic difficulties, to a certain extent, inhibit participants' progress in speaking English. 


\section{Table 7}

English-majored students' English speaking difficulties in terms of linguistic difficulties

\begin{tabular}{cccc}
\hline \multirow{2}{*}{ No. } & \multirow{2}{*}{ Items } & \multicolumn{2}{c}{ N=150 } \\
\cline { 3 - 4 } & & M & SD \\
\hline 11 & I do not have enough English vocabulary. & 2.85 & 1.07 \\
\hline 12 & I do not have enough English grammar knowledge. & 2.74 & 1.21 \\
\hline
\end{tabular}

Note: $\mathrm{M}=$ mean; $\mathrm{SD}=$ standard deviation

Source: The researcher's data analysis

\subsubsection{Difference in English-majored students' English speaking difficulties}

In terms of years of learning English, the results presented in Table 8 indicate that there was no significant difference in English speaking difficulties regardless of how many years English-majored students have spent learning English $(\mathrm{F}=1.590 ; \mathrm{p}=.207)$. Nevertheless, if elements of English speaking difficulties are taken into account, there were significant differences in affective difficulties ( $\mathrm{F}=3.046 ; \mathrm{p}=.036)$ and linguistic difficulties $(\mathrm{F}=3.565$; $\mathrm{p}=.031)$, but no significant differences in social difficulties $(\mathrm{F}=.245 ; \mathrm{p}=.783)$ and instructional difficulties $(\mathrm{F}=1.264 ; \mathrm{p}=.286)$. At this point, the Post hoc Tukey test was run to clarify the differences among the year groups.

\section{Table 8}

Difference in English-majored students' English speaking difficulties in terms of years spent learning English

\begin{tabular}{lccccc}
\hline \multirow{2}{*}{ Factors } & \multirow{2}{*}{ F } & Sig. & \multicolumn{3}{c}{ M(SD) } \\
\cline { 5 - 6 } & & & $\mathbf{5 - 7}$ years & $\mathbf{8 - 1 0}$ years & Over 10 years \\
\hline Affective difficulties & 3.046 & $\mathbf{. 0 3 6 *}$ & $3.64(.96)$ & $3.52(.89)$ & $3.15(.97)$ \\
\hline Social difficulties & .245 & .783 & $3.10(.84)$ & $3.05(.73)$ & $2.98(.94)$ \\
\hline Instructional difficulties & 1.264 & .286 & $2.25(.83)$ & $2.30(.74)$ & $2.51(.82$ \\
\hline Linguistic difficulties & 3.565 & $\mathbf{. 0 3} *$ & $3.02(1.01)$ & $2.79(1.05)$ & $2.49(.78)$ \\
\hline \multicolumn{1}{c}{ Overall } & 1.590 & .207 & $3.00(.64)$ & $2.92(.59)$ & $2.78(.59)$ \\
\hline
\end{tabular}

*The mean difference is significant at .05

Source: Data analysis result of research

As seen from Table 9 the results from the Post hoc Tukey test with significance at the .05 level reveal that the participants who have learned English from 5 to 7 years $(\mathrm{M}=3.64$; $\mathrm{SD}=.96)$ suffered affective difficulties more than those learning English for over 10 years $(\mathrm{M}=3.15 ; \mathrm{SD}=.97)(\mathrm{p}=.031)$. Similarly, the participants who have learned English from 5 to 7 years $(\mathrm{M}=3.02 ; \mathrm{SD}=.1 .01)$ also encountered linguistic difficulties more than those having learned English for over 10 years $(M=2.49 ; \mathrm{SD}=.78)(\mathrm{p}=.023)$. This can be referred that the longer English-majored students have learned English, the less affective difficulties and linguistic difficulties they had to endure when speaking English. 


\section{Table 9}

Post hoc Tukey test

\begin{tabular}{|c|c|c|c|c|c|}
\hline Dependent Variable & $\begin{array}{c}\text { (I) years of } \\
\text { Learning } \\
\text { English }\end{array}$ & $\begin{array}{l}\text { (J) years of } \\
\text { Learning } \\
\text { English }\end{array}$ & $\begin{array}{c}\text { Mean } \\
\text { Difference } \\
\text { (I-J) }\end{array}$ & $\begin{array}{l}\text { Std. } \\
\text { Error }\end{array}$ & Sig. \\
\hline \multirow{6}{*}{ Affective difficulties } & \multirow{2}{*}{$5-7$} & $8-10$ & .122 & .181 & .779 \\
\hline & & over 10 & .492 & .192 & $.031 *$ \\
\hline & \multirow{2}{*}{$8-10$} & $5-7$ & -.122 & .181 & .779 \\
\hline & & over 10 & .370 & .197 & .150 \\
\hline & \multirow{2}{*}{ over 10} & $5-7$ & -.492 & .192 & $.031 *$ \\
\hline & & $8-10$ & -.370 & .197 & .150 \\
\hline \multirow{6}{*}{ Linguistic difficulties } & \multirow{2}{*}{$5-7$} & $8-10$ & .223 & .187 & .457 \\
\hline & & over 10 & .529 & .198 & $.023^{*}$ \\
\hline & \multirow{2}{*}{$8-10$} & $5-7$ & -.223 & .187 & .457 \\
\hline & & over 10 & .306 & .204 & .293 \\
\hline & \multirow{2}{*}{ over 10} & $5-7$ & -.529 & .198 & $.023 *$ \\
\hline & & $8-10$ & -.306 & .204 & .293 \\
\hline
\end{tabular}

*The mean difference is significant at the .05 level

Source: Data analysis result of research

\subsection{Discussion}

This study has yielded two significant results. Firstly, the overall findings have revealed that English-majored students' speaking abilities were often affected by difficulties. One of the possible reasons may be that they often spend time practicing their speaking skills. Their background information reveals that they allocate at least 1 hour per day to self-practice English speaking skills (as seen in Table 1), and some of them even spend more than 3 hours per day practicing speaking skills.

As for English speaking difficulties, English-majored students were most affected by affective difficulties but least influenced by instructional difficulties when speaking English. It may be agreed that personal affective traits such as anxiety, low self-confidence and mistakephobia are humane natural traits, and they are intrinsic personal traits. That may be why English-majored students were most influenced by affective difficulties when speaking English. This finding is partly similar to that of Juhana (2012) which considers affective difficulties as factors often hindering students from speaking English. In line with this, Xiuqin (2006) also confirmed that English-majored students face speaking difficulties such as being afraid of making mistakes, fear of public speaking, and shyness of speaking. Meanwhile, instructional difficulties such as instructors' L1 overuse, harsh error correction, low command of English speaking skills and low encouragement are extrinsic motivations. It may be obvious that such difficulties do not hinder students from speaking English in class. Or it may be the fact that research participants' instructors may not overuse L1, correct students' errors harshly, have low command of English speaking skills and encourage students to speak English, so they do not experience such difficulties while speaking English. 
Furthermore, social and linguistic difficulties affected students' speaking skills moderately. Regarding social difficulties, English-majored students often lacked opportunities to practice speaking English outside the classroom, but they sometimes had difficulty in cooperating with their class in speaking class. This is understandable because English is used as a foreign language in Vietnam, so there are few opportunities for the students to practice speaking English outside the classroom and the personal traits as discussed above entail their cooperation with others in speaking class. With respect to linguistic difficulties, this type of difficulty is obviously bearable as English-majored students can cope with such difficulties. One reason is that many English-majored students seem to possess at least an average level of English proficiency, so they do not suffer many difficulties in terms of linguistic difficulties. This finding is contrary to Atas' (2014) discovery that students often encountered English speaking difficulties due to lack of vocabulary limited grammar.

The second major finding is that the extent to which English-majored students have difficulty in speaking English depends on the length of English learning time. The more they have learned English, the less English speaking difficulties they suffered. One of the possible explanations for this may be that when learning English long enough, English-majored students may find appropriate learning strategies to overcome such English speaking difficulties. They may become more confident, less anxious and less afraid of making mistakes in speaking English. In addition, they may have good linguistic knowledge to avoid mistakes and errors while speaking English. It may be claimed that speaking difficulties do not hinder Englishmajored students much from speaking English if they have learned English long enough.

\section{Conclusion}

This study has indicated that English-majored students often experience speaking difficulties, and such speaking difficulties can vary in terms of the length of English learning time. Therefore, it is imperative that English-majored students should seek out or create more opportunities to practice speaking English more often as practice makes perfect. Furthermore, students should be self-motivated to look for chances to speak English wherever and whenever possible, for example taking part in classroom activities such as pair-work, group work, class discussions, joining English clubs, making friends with better learners and native speakers, traveling to the country where English is spoken natively, and so on. Besides, students should take risks wisely to present a difficult topic in front of the class or bravely choose a difficult task. They need to realize that making some mistakes in speaking English is the natural phenomenon of any non-native speaker of English, especially learners of English at the early stage. When students are brave enough to overcome their inhibitions to start speaking English once, they will feel more confident and use English more often. As a result of that, they may improve their speaking English competence remarkably. One more thing is that the computer is not strange to students and many of them can own a PC or laptop nowadays, so they should use sound recorder software to record their voice and evaluate it with the native speaker's voice. Students should put more effort into practicing English sounds. Consequently, some mistakes can be recognized, corrected and their pronunciation will be improved significantly. Regarding recommendations to teachers, they should allow students to talk about their English speaking difficulties, ask questions, and share good-experience or effective ways of learning English that they have tried. The teachers should make clear about their sympathetic behavior to weak students so that they 
dare to confide to teachers about their problems. Teachers should move around the class, talk to students to find out some weak students and help them overcome their inferior complex. Thanks to the teacher's encouragement, weak students can feel more confident in communicating with their peers in English. The more English-majored students speak English, the more confident they feel. The more confident they feel, the more English they will use.

This study still bears some limitations. Firstly, the research design is pure quantitative research. Secondly, only one research instrument, a questionnaire, was employed to collect the data. Last but not least, the number of research participants is, to some extent, small. Therefore, further and duplicated research should take such limitations into account

\section{References}

Aleksandrzak, M. (2011). Problems and challenges in teaching and learning speaking at advanced learning. Glottodidactica, 37, 37-48.

Atas, M. (2014). The reduction of speaking anxiety in EFL learners through drama techniques. Procedia - Social and Behavioral Sciences, 17(6), 961-969.

A-Hosni, S. (2014). Speaking difficulties encountered by young EFL learners. International Journal on Studies in English Language and Literature (IJSELL), 2(6), 22-30.

Beebe, L. M. (1983). Risk-taking and the language learner. In H. W. Seliger \& M. H. Long (Eds.), Classroom oriented research in second language acquisition. Rowley, MA: Newbury House Publisher.

Berns, M. (1990). Contexts of competence: Social and cultural considerations in communicative language teaching. New York, NY: Plenum Press.

Brown, H. D. (1994). Principles of language learning and teaching. Upper Saddle River, NJ: Prentice Hall.

Carrasquillo, A. L. (1994). Teaching English as a second language: A resource guide. New York, NY: Garland publishing Inc.

Hojat, A., \& Afghari, A. (2013). An investigation of speaking-associated problems from students and instructor perspectives. Iranian EFL Journal, 9(4), 9-31.

Juhana, H. (2012). Psychological factors that hinder students from speaking in English class (A case study in a senior high school in South Tangerang, Banten, Indonesia). Journal of Education and Practice, 3(12), 100-110.

Nawshin, F. (2009). Problems in teaching speaking in traditional ESL classroom (Bachelor's thesis, BRAC University, Bangladesh). Retrieved October 24, 2016, from http://dspace.bracu.ac.bd/xmlui/handle/10361/137

Nguyen, T. H., \& Tran, M. N. (2015). Factors of teaching students' speaking difficulties at Le Then Hien high school. Asian Journal of Educational Research, 3(2), 8-23.

Scollon, R., \& Scollon, S. (1990). Athabaskan and English interethnic communication. In D. Carbaugh (Ed.), Cultural communication and intercultural contact. Hillsdale, NJ: Lawrence Erlbaum. 
Shumin, K. (1997). Factors to consider: Developing adult EFL learners' speaking abilities. Teaching Forum, 35(3), 8-10.

Tran, T. Q., \& Dang, H. V. (2014). Culture teaching in English language teaching: Teachers' beliefs and their classroom practices. Korea TESOL Journal, 11(1), 207-223.

Tran, T. Q., \& Nguyen, L. T. T. (2019). Teaching English grammar communicatively: A critical look at the roles of English grammar in the EFL context. Paper presented at the International Conference Autonomy and Motivation for Language Learning in The Interconnected World, Ho Chi Minh City University of Technology and Education, Vietnam.

Tran, T. Q., \& Tham, D. M. (2015). Intercultural language teaching: Rethinking the objectives of English language education in the Vietnamese context. English for specific purposes World, 15(46).

Tsui, A. B. M. (1996). Reticence and anxiety in second language learning. In K. M. Bailey \& D. Nunan (Eds.), Voices from the language classroom (pp. 145-167). Cambridge, UK: University Press.

Ur, P. (1999). A course in language teaching: Practice and theory. Cambridge, UK: Cambridge.

University Press.Xiuqin, Z. (2006). Speaking skills and anxiety. CELEA Journal (Bimonthly), 26(1), 34-39. 